\title{
Developing supplementary English reading materials for Vocational High School
}

\author{
Hanswaty Noho ${ }^{* 1}$, Hasanuddin Fatsah ${ }^{2}$, Rasuna Talib ${ }^{3}$ \\ ${ }^{1}$ SMK Almamater Telaga, Gorontalo, Indonesia \\ *e-mail: hanswathyn@gmail.com \\ ${ }^{2,3}$ Universitas Negeri Gorontalo, Gorontalo, Indonesia \\ e-mail: ${ }^{2}$ hasanuddin@ung.ac.id; ${ }^{3}$ rasunat68@yahoo.com
}

\begin{abstract}
The main problem of this study was "What are students of the Vocational School of Computer Networks need in learning English?" and "How is the development of supplementary English materials for reading skill?" The objective aimed at describing the development of supplementary reading materials for the tenth-grade vocational school based on the 2013 curriculum. The subject was the computer networks students in grade tenth in the 2015/2016 academic year consisting of twenty-two students (five males and 17 females). This research used R \& D (Research and Development) method. The data were gathered from a number of sources, including students' need analysis of English reading materials in grade X in the students' book of 2013 curriculum, supplementary development of the English reading materials for computer networks students, and expert validation of supplementary English reading materials and students' response after used the supplementary English materials. The findings showed that more than $30 \%$ of students were difficult to read the computer networks text and to understand the meaning of the text. The result of students' book analysis was none of the reading materials appropriate for computer networks department, mostly provided General English. In developing the supplementary English reading materials for computer networks students, there were four stands, in which the current research only applied three out of the four stands, including define, design and developed. This supplementary English reading material helped the computer networks students to learn English based on their need.
\end{abstract}

\section{Keywords:}

English supplementary materials; English for computer networks; materials development

\section{INTRODUCTION}

The government of Indonesia is struggling to decrease the number of unemployment through several attempts such as supporting the vocational education. In vocational high school, students are expected to be ready to enter several work fields such as architecture, welding, automotive, and the famous computer networks department. In attempts to enhance the aims of vocational education, equipping students with English is a necessity before entering the work industry.

This phenomenon urges the teachers to design the learning materials themselves. However, teachers are too busy with teaching and managing some of the school administrative duties. Moreover, most of the teachers are also 
unable to design the materials since they were not taught how to design textbook during studying in the university.

Another problem is the change of curriculum from KTSP or Curriculum 2006 to 2013 Curriculum (Iskandar, 2017). The curriculum shift requires the change of the textbooks due to the differences between the context of the textbooks within the Curriculum 2006 and 2013 curriculum respectively. For vocational high schools, especially in the computer networking program, the course book that suits to the 2013 Curriculum is not available yet. In response to this, English learning materials for tenth-grade students in the computer networking program, particularly in SMK Almamater Telaga, should be enhanced.

Masuhara and Tomlinson (2008) revealed that it is not always easy to seek appropriate materials that can meet the students' need. This study is expected to help and ease the teacher in finding appropriate and sufficient supplementary materials to the learners' need for reading skill based on the 2013 curriculum. The researcher would like to apply a scientific approach as the activities in the supplementary reading materials book. The teacher can use it as an additional source of teaching reading based on the 2013 curriculum and also it can be used by the students to learn reading inside or outside of the class. With the supplementary reading materials, the teacher will not get any difficulties in finding the appropriate materials in teaching reading. Additionally, the students can explore and enhance more their reading skill.

Reading often deals with long texts. Unfortunately, many students get instantly bored just when getting such texts. Moreover, their boredom easily leads them either to loss of motivation or low awareness. Teaching English in vocational high schools is different from teaching English in senior high schools. This refers to the purposes of the teaching of both the education level. In vocational high schools, English must be based on the students' needs and must be relevant to their field of study (Jun Zhang \& Bin Anual, 2008). English is an adoptive subject in which aims to provide students the ability to communicate based on the communicative materials needed for the students' program, both written and spoken.

Teaching English in vocational high schools is classified as English for Specific Purposes (ESP) (Sumarni, Fauzan, Mofreh, \& Patak, 2018). This because the lesson is specific to a specific area based on the students' needs. ESP is an approach of language teaching in which the designing of the content and deciding the method is based on the learners' needs (Hutchinson \& Waters, 1987). It is clear that the root of ESP is the learners' needs because their needs are specific to a particular area, not only general English that is taught in other formal school levels.

What distinguishes ESP from General English is the awareness of the needs. In ESP, the materials are developed based on learners' needs. That means that conducting a needs analysis is compulsory. Needs analysis can be defined as the process of analyzing the learners' needs. Brown and Abeywickrama (2010) defines the term of needs analysis as the activities involved in gathering information to serve as the beginning for developing a curriculum which meets the learning needs of a particular group of students. 
Once identified, the needs can be stated regarding goals and objectives which, in turn, can serve as the centers for developing tests, materials, teaching activities, and evaluation strategies.

Thus, it is necessary to develop supplementary reading materials for the tenth-grade students of vocational school based on the 2013 curriculum. The researcher intends to provide the solution to the above mentioned by doing research entitled "Developing Supplementary Reading Materials for Tenth Grade at Computer Networking of SMK Almamater Telaga."

\section{METHOD}

This research applies Research and Development (R \& D) method. The R\&D procedures consist of 4 - D models. It stands for Define, Design, Develops, and Disseminate (Thiagarajan, 1974). The current research only applies three out of the four methods, which are Define, Design and Develop and was conducted at SMK Almamater Telaga, Gorontalo, Indonesia. The subjects of this research were the first-grade students of SMK Almamater Telaga in the second semester in 2015/2016 academic year. They consisted of twenty-two in Computer Networks Program. Techniques for analyzing the data in this research are descriptive analysis techniques.

\section{FINDING AND DISCUSSION}

A need analysis was conducted as the first stage of the research to assess the learning needs of the students. The questionnaire was distributed on 19th October 2016. The questionnaire was in the form of choices questions. There were some questions in which the students were allowed to choose more than one option. The following tables describe findings gained from students ${ }^{\text {ee }}$ responses toward the questionnaire. Those results are analyzed separately and need analysis questionnaire put more concern in learning needs of the students. The highest percentage of the student respondents are $63.60 \%$ stated that the skill they need most is reading. Writing skill got $39.47 \%$ of student respondents. The students were asked about what skill they found difficult. About half of them stated that reading is the most challenging skill and the second one is writing besides speaking is $15.78 \%$ and listening skill is $23.68 \%$.

The researcher put Reading skills in this indicator because there are two reasons. First, students of Computer Networks of SMK Almamater Telaga focus more on learning reading than another skill. Second, in this indicator there are eight aspects of students' difficulties in learning reading such as understanding the main points of text, reading text quickly (skimming), reading a text slowly and carefully, scanning, guessing unknown words in a text, understanding text organization, understanding vocabulary in a text, reading speed and criticize the text. Guessing unknown words in a text, understanding text organization and understanding vocabularies in a text are the individual terms, which become the most challenging aspect for students in reading skill. The percentage is more than $30 \%$.

Based on the characteristic of ESP, computer networks students should learn the material which is based on their need. In fact, according to the Regulation of Minister of Education and Culture Number 702013 year, the

DOI: 10.33750/ijhi.v1i2.12

ISSN: 26146169

@Center for Humanities and Innovation Studies 
basic competencies for grade $\mathrm{X}$ students of vocational high school found that none of the material matched with the students' need. The result of analysis showed that the reading material for basic competences self-introduction (3.1 -4.2), complimenting (3.2 - 4.3), caring/expression of showing attention (3.3 - 4.4), intention to do something (3.4 - 4.5), expression of congratulating someone $(3.5-4.6)$, recount text $(3.6-4.7)$, and descriptive texts related to person, tourism object, and historical $(3.7-4.10)$ just covered GE rather than ES P. So, in this research, the reading materials were developed to become English reading materials for computer networks students in which all the contents for every basic competence are more suitable with the computer networks students' need. The developed reading material is applied in teaching and learning activity; one unit one meeting, about $2 \times 45$ minutes for every meeting.

In the need analysis of reading skill, guessing unknown words in a text, understanding text organization and understanding vocabularies in a text are the particular terms that become the most challenging aspect for students in reading skill. These needs had been proved that with 19 students, $39.47 \%$ students often did not know to guess words and vocabularies and $47.37 \%$ students often did not understand text organization. However, in the frequency of difficulties, the highest percentage $47 \%$ of student respondents stated that they found it difficult to read the text about computer networks text.

Beside need analysis for students, it is also essential to analyze the curriculum and the students' textbook. According to Tomlinson (2011); Tomlinson (2003) that there should be a course syllabus which will indicate what kind and what amount of materials are needed. The 2013 curriculum is current curriculum used that is different to KTSP in which four language skills are taught separately. In 2013 curriculum the four skills of English: listening, writing, reading and speaking are taught in an integrated way. The teachers will not teach one skill in one cycle, but they will integrate those skills into one cycle to create the interactive teaching and learning process.

Unfortunately, the English syllabus and textbook of Senior High School and Vocational High School are the same. The syllabus and the students' textbook contain General English (GE), and it is not appropriate for the Vocational High School students. The students need kinds of material related to their specific need. It means that the content of material should relate to their disciplines. Because of this, the English teachers of Vocational High School need to be more creative in designing the supplementary material for students.

Developing supplementary material also needed analysis of curriculum. Based on the finding that the 2013 English curriculum consisted of primary and essential competencies. The analysis of basic competence and the material in the students' book. In fact, the materials of computer networks text, descriptive text, and recount text were still too less because each text is mostly general text. Each material in two main competencies were developed into two or four necessary competencies. The activities guided students to practice their reading skill and motivate them to be active in the learning process. So they would be interested because they had a chance to expose their competence. Developing supplementary material is based on the framework of developing 
material by Thiagarajan (1974). Based on the finding, it revealed that not all the frameworks were used in the developing supplementary material in this research. It is because that in 2013 curriculum, the government had supplied books for students but based on the result of analysis of curriculum especially materials for reading, the materials should be developed, so students had the competency to use English for their future. The developing supplementary materials for reading skill followed some frameworks in this research. They were defined, design, and develop.

The define includes some steps. The first step was to see the curriculum of vocational high school which is related to the English syllabus of 2013 curriculum. It aimed to find out which one of the materials suitable for the students' need. The second step was the learner analysis. The learner analysis was a step in which the researcher or the teacher identified the students' characteristics that include competencies, abilities, background experiences, knowledge and skills. Task analysis is the identification of the primary skill to be required by the teacher and analyzing it into a set of necessary and sufficient sub-skills. It means that task analysis is used to analyze the material and main skills that will be developed in preparation of the supplementary material. The fourth step is the concept analysis. Concept analysis is used to identify the primary concepts to be taught and systematically arranged. It means that identifying the central concepts that will be presented in the materials being developed. Reading material that is taught on computer networks is a matter that has to do with their majors such as reading the text about the discovery of computer. It is not only about computer networks in the text but also reading about people, tourist attractions and famous in Gorontalo regency like Limboto lake, Bandayopoboide traditional house. Students interested in much reading presented and acquire their new knowledge. The fifth step is specifying instructional objectives. This set of objectives provided the basis for test constructional and instructional materials for used by teacher and students. Formulation of instructional objective based on the main competencies and necessary competencies contained in the 2013 curriculum. The main competencies were cognitive, and skill and then essential competencies were separated into two or four activities.

The second stage designs. In this stage, there were two kinds of steps. The first step is the format/media selection. The researcher used media like pictures, videos, and a whiteboard. The process of selecting media adapted to the analysis results of the task, concept and the student's characteristics. The media like a video about someone who repairs a computer. The second step is the initial design. This step aims to produce a preliminary design of prototype products and to prepare the product developed. Based on the English teacher and expert response, there were some revisions in the supplementary English reading material such as added the list of difficult words and consistent to the task.

The third stage is developed. The development of supplementary material is only two steps. They were an expert appraisal and developmental testing. This step aims to obtain feedback and suggestions to enhance the supplementary reading. The researcher asked for the adviser as media expert. The expert gave comments and suggestions like pay attention to the generic DOI: $10.33750 /$ ijhi.v1i2.12 
structure of recount and descriptive text, gave greeting card more than one, put the language element before or after reading. After that, the researcher made three-time revisions of supplementary material. As Tomlinson (2003) studied that revision is the stage to produce an improved version of the materials.

The final step is to disseminate developmental testing. After revising the draft of supplementary material, the draft tested to the students of SMK Almamater Telaga. Although only nineteen students in the classroom, they were interested and enjoyed to study English. It can be seen in the students' response after using the supplementary material. Based on the explanation above, the researcher concluded that this supplementary English reading material is very beneficial for computer networks students because they got a chance to learn English based on their major. Although this supplementary English reading material does not have any contribution to the National examination, this could be a suggestion for government primarily for education and culture ministry in order to develop the curricula to create different English syllabus and English students' book for Vocational High School

\section{CONCLUSIONS}

There are two supplementary materials which have been developed in this research; they are "computer networks Text and history text." There is too analysis to support developing supplementary materials. They are an analysis of students' needs and developing supplementary material. The first analysis is about students' needs to learn reading English. The result of students' needs analysis is based on their problems in reading English; those are (1) vocabularies in a text; (2) guessing unknown words; (3) understanding text organization; the second analysis is English reading material. The result of English reading analysis is the materials in students' book that is the same with Senior High School. This is because the syllabus only covers General English that is not appropriate for their principal.

Developing Supplementary materials for reading English to follow the frameworks for materials development (Thiagarajan, 1974). The frameworks for material development, those are (1) Define stage are front-end analysis, learner analysis, task analysis, concept analysis and specifying instructional objectives; (2) Design stage is Media/Format analysis and initial design; (3) Develop are an Expert appraisal and Developmental testing (Supplementary material final). This research used to research and development (R\&D) methodology. Research and development (R\&D) is the methodology of this research. Based on the frameworks for materials development and methodology of $\mathrm{R} \& \mathrm{D}$, this research results in one product which becomes supplementary materials for reading skill.

The product is supplementary English reading material for Computer networks students' tenth grade in Vocational High School. This product has been evaluated, revised, tried out only one class. The result of the trialing of advanced supplementary materials gains good responses from students because they never learn such materials before. The English teacher is grateful because it helped them to teach students especially computer networks program. 
The form of advanced supplementary materials for reading consists of "text, language, and activities." This development materials cover the presentation of the explanation of materials, a list of vocabularies and task activities. The characteristics of the materials which have been developed in this research are interesting, useful, fulfilling students' needs and match with the 2013 curriculum. They can get comprehension and knowledge about computer networks, inventor of the computer and traditional house in Gorontalo.

\section{REFERENCES}

Brown, H. D., \& Abeywickrama, P. (2010). Language Assessment: Principles and Classroom Practices. Pearson Education.

Hutchinson, T., \& Waters, A. (1987). English for specific purposes. Cambridge University Press.

Iskandar. (2017). School-based EFL curriculum implementation in Indonesian primary schools: A perspective of Bernstein's pedagogic device. Asian EFL Journal, 8, 3642.

Jun Zhang, L., \& Bin Anual, S. (2008). The Role of Vocabulary in Reading Comprehension. RELC Journal, 39(1), 51-76.

Masuhara, H., \& Tomlinson, B. (2008). Materials for general English. English Teaching Materials: A Critical Review, 17-37.

Sumarni, S., Fauzan, M. M., Mofreh, S. A. M., \& Patak, A. A. (2018). Investigating students' reflection toward self-assessment on creative writing achievement in ESP course. International Journal of Humanities and Innovation (IJHI), 1(1), 8-16.

Thiagarajan, S. (1974). Instructional development for training teachers of exceptional children: A sourcebook.

Tomlinson, B. (2003). Developing materials for language teaching. A\&C Black.

Tomlinson, B. (2011). Materials Development in Language Teaching. Cambridge University Press. 